\title{
THE EFFECT OF ACCOUNTABILITY, TRANSPARENCY, AND SERVICE QUALITY TOWARD LOYALTY OF ZAKAT PAYERS
}

\author{
Izhar Allessandria Mardini \\ Faculty of Economics and Business \\ Universitas Jenderal Soedirman \\ E-mail (Corresponding Author): izhar.alles@gmail.com \\ Bambang Agus Pramuka \\ Faculty of Economics and Business \\ Universitas Jenderal Soedirman \\ Negina Kencono Putri \\ Faculty of Economics and Business \\ Universitas Jenderal Soedirman
}

\begin{abstract}
Zakat can become a significant source of state revenue. This can be realized if the people of Islam in Indonesia obedient in paying the zakat. Besides, the zakat institution in charge of managing the zakat must be honest, transparent and accountable in managing the zakat so that can increase the confidence of zakat payers (muzakki). But in reality, until this time there are still found a lack of potential for the payment of zakat in Indonesia. There are several factors that lead to loyalty of zakat payers that will increase zakat collection, such as accountability, transparency, and service quality applied by zakat management organization.This study aims to examine the effect of accountability, transparency, and service quality toward loyalty of zakat payers. This research is a quantitative study with primary data from questionnaires distributed to zakat payers of zakat management organization in Purwokerto. Sampling technique uses a convenience sampling method. There are 100 respondents that fulfilled questionnaires. Data analysis technique used is multiple regression analysis. The results of this study indicate that accountability, transparency, and service quality have a significant and positive effect toward loyalty of zakat payers.
\end{abstract}

Keywords: Accountability, Transparency, Service Quality, Loyalty of Zakat Payers

\section{ABSTRAK}

Zakat dapat menjadi sumber pendapatan negara yang signifikan. Ini bisa terwujud jika umat Islam di Indonesia taat dalam membayar zakat. Selain itu, lembaga zakat yang bertugas mengelola zakat harus jujur, transparan, dan akuntabel dalam mengelola zakat sehingga dapat meningkatkan kepercayaan pembayar zakat (muzakki). Namun pada kenyataannya, hingga saat ini masih ditemukan kekurangan potensi pembayaran zakat di Indonesia. Ada beberapa faktor yang menyebabkan loyalitas pembayar zakat yang akan meningkatkan pengumpulan zakat, seperti akuntabilitas, transparansi, dan kualitas layanan yang diterapkan oleh organisasi 
manajemen zakat. Penelitian ini bertujuan untuk menguji pengaruh akuntabilitas, transparansi, dan kualitas layanan terhadap loyalitas pembayar zakat. Penelitian ini adalah penelitian kuantitatif dengan data primer dari kuesioner yang dibagikan kepada pembayar zakat di organisasi pengelola zakat di Purwokerto. Teknik pengambilan sampel menggunakan metode convenience sampling. Ada 100 responden yang mengisi kuesioner. Teknik analisis data yang digunakan adalah analisis regresi berganda. Hasil penelitian ini menunjukkan bahwa akuntabilitas, transparansi, dan kualitas layanan berpengaruh signifikan dan positif terhadap loyalitas pembayar zakat.

Kata Kunci: Akuntabilitas, Transparansi, Kualitas Pelayanan, Loyalitas Pembayar Zakat

\section{INTRODUCTION}

Indonesia is a developing country, where some of the populations are still classified as poor people. Based on Badan Pusat Statistik's data that recorded until September 2017, there are 26.58 million populations or equivalent to $10,12 \%$ of the Indonesian population are classified as poor people. The poverty rate is still relatively high. The government requires an instrument to reduce poverty and income distribution. Demographically, the majority of the population in Indonesia is Muslim. In Islam, there are 5 pillars of Islam that are required to run by every Muslim, one of them is zakat. Zakat is the amount of wealth that certain required issued by every Muslim and given to those who are eligible to receive that has been specified in the Al-Quran. Zakat is the worship of the horizontal dimensions in human relationships. The equality defines zakat is very basic and fundamental to the religion of Islam. In Surah At-Tawbah verse 60 mentioned that there are 8 classes who are entitled to receive zakat.

On the macro point of view, zakat can become a significant source of state revenue. This can be realized if the people of Islam in Indonesia obedient in paying the zakat. Besides, the zakat institution in charge of managing the zakat must be honest, transparent and accountable in managing the zakat so that can increase the confidence of zakat payers (muzakki). But in reality, until this time there are still found a lack of potential for the payment of zakat in Indonesia.

In Indonesia, the management of zakat is regulated by the UU No. 232011 set about the management of zakat and its derivative regulation summarized in the PP No. 14/2014 and Inpres No. 3/2014. One of the great ideas of zakat management arrangement contained in UU No. 232011 and covers the entire article is integrated management. The word integrated becomes the principle that underlies the activities of the zakat management in our country, whether conducted by Badan Amil Zakat Nasional (BAZNAS) at all levels and Lembaga Amil Zakat (LAZ) that gets the legality of in accordance with the provisions of the legislation.

The management of zakat need to understand the existence of UU No. 23 The year 2011 about the management of zakat which will be equipped with the PP on the implementation of the UU, that actually aims to arrange better management of zakat. The arrangement referred to is not apart from the interests to make zakat institution more professional, have the legality 
of formal juridical and follow the responsibility system to the government and society. The duties and responsibilities as zakat institution cannot be separated from the principles of shari'a that associate zakat with government authority to raise zakat institution. Zakat can influenced by several factors such as transparency, accountability, and service quality from zakat management organization.

The importance of this research is because the dominant factors that influence the loyalty of zakat payers are that the zakat management organization which is transparent, accountable, and provides good and satisfying services. Beside that, this research aim to know how to optimize the potential of zakat in Indonesia.

\section{LITERATURE REVIEW AND HYPOTHESIS DEVELOPMENT Consumer Trust Theory}

According to Peppers and Rogers (2004), consumer confidence is a quality that reflects the good relationship between the person with the other party. Consumers have trust in the organization through the activities of the organization. While according to Mayer et al (1995), consumer trust is defined as the willingness of a party to accept the risk from the actions of another party based on the expectation that the other party will take an important action for the party who believe them, regardless of the ability to supervise and take action of the party who trusted. Consumer trust is one of the fastest ways to build a long-term organizational relationship. Only through consumer trust in relation, information can be returned to the organization. Trust plays a role in improving the ability of consumers to make choices, trust-based relationships.

\section{Sharia Compliance}

Theory of Planned Behavior (TPB) is the development of Theory of Reasoned Action (According to Widialoka et al (2015), shari'a compliance has international standard that has been arranged and set by the Islamic Financial Service Board (IFSB), where shari'a compliance is part of the governance of the institution. The principles of shari'a compliance is transparency, accountability, responsibility, professionalism, and fairness. Shari'a compliance refers to the rules and the way of life that is determined by Allah SWT for his servant. In relation to this research, shari'a compliance is the implementation of shari'a principles which refers to the rules of Allah SWT in the zakat management. The compliance of the shari'a in the management of zakat is a must on every manager of zakat. It is not only related to the trust of zakat payers towards zakat institution, but more important and fundamental is regarding the moral values and responsibility of the instituion to Allah SWT as the owner of the shari'a

\section{The Effect of Transparency to Loyalty of Zakat Payers}

Transparency can affect the loyalty of zakat payers because the zakat management financial report is clear and in accordance with the existing reporting evidence so that the zakat payers can know clearly the management of zakat funds provided. The more transparent the management of zakat by zakat management organizations, zakat payers will be more confident and will tend to deliver zakat to zakat management organization.

\section{$\mathrm{H}_{1}$ : Transparency positively influence loyalty of zakat payers}




\section{The Effect of Accountability to Loyalty of Zakat Payers}

Accountability can affect the loyalty of zakat payers because accountability is the responsibility of the zakat management organization to the payers of zakat. The more accountable a zakat management organization, the zakat payers will become more trust and will tend to pay zakat to the zakat management organization because the responsibility is clear.

\section{$\mathrm{H}_{2}$ : Accountability positively influence loyalty of zakat payers}

\section{The Effect of Service Quality to Loyalty of Zakat Payers}

Quality of service can affect the loyalty of zakat payers because the satisfaction of the payers of zakat is affected by whether good or not the services obtained, whether easy or not the procedure of zakat payment in zakat management organization. The better the quality of service in the organization of zakat management, the higher the trust of zakat payers that will affect the zakat payers loyalty that will be higher to pay zakat on the zakat management organization.

\section{$\mathbf{H}_{3}$ : Service Quality positively influence Loyaty of Zakat Payers}

\section{RESEARCH METHODOLOGY}

\section{Research Types}

This type of research used in this study is quantitative research by processing data from the results of the questionnaire.

\section{Research Objects}

The object of this research are muzakki of zakat management organization in Purwokerto.

\section{Population}

The population in this study is all zakat payers of zakat management organization in Purwokerto.

\section{Sample}

This research used convenience sampling method. In this research, the author takes 100 zakat payers of zakat management in Purwokerto as samples.

\section{Data Collection Method}

Collecting primary data in this study by distributing questionnaires to zakat payers of zakat management organization in Purwokerto.

\section{Operational Variable}

Table 3.1

Variable Operationalization

Independent Variables (X1): Transparency

\begin{tabular}{llc} 
Variable & \multicolumn{1}{c}{ Indicator } & Scale of data \\
\hline Transparency & 1. Easy access to information. & Ordinal \\
& 2. Information can be compared. & Ordinal \\
3. Completeness information. & Ordinal \\
4. Relevance. & Ordinal \\
5. Zakat Management & Ordinal
\end{tabular}


Organization has included parties who become zakat payers.

Ordinal

6. Information equalization.

Ordinal

7. Clear source of funds.

Ordinal

8. Clear distribution of funds.

Table 3.2

Variable Operationalization

Independent Variables (X2): Accountability

\begin{tabular}{llc} 
Variable & \multicolumn{1}{c}{ Indicator } & Scale of data \\
\hline Accountability & 1. Honesty. & Ordinal \\
& 2. Periodically and on time. & Ordinal \\
3. Easy access to information. & Ordinal \\
4. According to standard and & Ordinal \\
& regulation. &
\end{tabular}

Table 3.3

Variable Operationalization

Independent Variable (X3): Service Quality

\begin{tabular}{|c|c|c|}
\hline Variable & Indicator & Scale of data \\
\hline \multirow[t]{6}{*}{ Service Quality } & 1. Performance. & Ordinal \\
\hline & 2. Service waiting room. & Ordinal \\
\hline & $\begin{array}{l}\text { 3. The reliability of } \\
\text { officers in providing } \\
\text { service information. }\end{array}$ & Ordinal \\
\hline & $\begin{array}{l}\text { 4. Administrative } \\
\text { capabilities of service } \\
\text { officer. }\end{array}$ & Ordinal \\
\hline & $\begin{array}{l}\text { 5. Hospitality of service } \\
\text { personnel. }\end{array}$ & Ordinal \\
\hline & $\begin{array}{l}\text { 6. Response of service } \\
\text { officer to citizen } \\
\text { complaints }\end{array}$ & Ordinal \\
\hline
\end{tabular}


Table 3.4

Variable Operationalization

Dependent Variable (X4): Loyalty of Zakat Payers

\begin{tabular}{llc} 
Variable & \multicolumn{1}{c}{ Indicator } & Scale of Data \\
\hline Loyalty of Zakat Payers & $\begin{array}{l}\text { 1. } \\
\text { Makes service usage } \\
\text { regularly. }\end{array}$ & Ordinal \\
2. Refers others. & Ordinal \\
3. & No intention of \\
& moving. & Ordinal \\
4. & Talk about positive \\
& things about the \\
& services used & Ordinal \\
& &
\end{tabular}

\section{Descriptive Statistics Analysis}

The descriptive statistical test is performed to find out and obtain descriptions of the data used in the study of mean, standard deviation, variance, minimum value, maximum value 5, range, etc. (Ghozali,2016). Descriptive statistics provide clearer and easier to understand data interpretations.

\section{Validity Test}

Validity test is used to measure the validity or validity of a questionnaire. A questionnaire is said to be valid if the question on the questionnaire is able to reveal something that will be a measured by the questionnaire. The criterion used is if $r$ count is greater than $r$ table ( $r$ arithmetic> $r$ table), then the data is said to be valid. Significant levels used (Ghozali, 2016). The significant level used in this study is $5 \%$.

\section{Reliability Test}

Reliability test is used to measure a questionnaire that is an indicator of a variable or construct. A questionnaire is said to be reliable if one's response to a statement is consistent over time (Ghozali, 2016: 47). The technique used in this study is Cronbach Alpha. A variable is said to be reliable if it gives a Cronbach Alpha value $>0.60$.

\section{Multicollinearity Test}

Tolerance measures the variability of selected independent variables that are not explained by other independent variables. Thus, a low Tolerance value equals a high VIF value (because VIF $=1 /$ Tolerance). Common cutoff values used to indicate the presence of multicolinality are Tolerance values $\leq 0.10$ or equal to $\mathrm{VIF} \geq 10$ (Ghozali, 2016).

\section{Normality Test}

The normality test is performed to test whether in the regression model, the intruder or a residual variable has a normal distribution. In this study, normalitias test using Kolmogorov Smirnov (KS) test. If probability value $>0.05$ then Ho is accepted (normally distributed) whereas if probability value $<0.05$ then Ho is rejected (not normally distributed). 


\section{Heteroscedasticity Test}

In this study, heteroscedasticity was performed by Glejser Test. The Glejser Test is performed by regressing the independent variables with its residual absolute value. If the value of significance between independent variables with absolute residual is more than 0.05 then there is no problem of heteroscedasticity.

\section{Coefficient Determination Test (Adjusted R Square)}

In the Adjusted R2 column can be seen what percentage can be explained by the independent variables to the dependent variable. The adjusted $\mathrm{R}^{2}$ value is between zero and up to one. The value of $\mathrm{R}^{2}$ which is close to one means the ability of the independent variables gives almost all the information needed to predict the variables dependent (Ghozali,2005).

\section{T-Test}

The $\mathrm{t}$ test is known as the partial test, used to test how the influence of each independent variable individually to the dependent variable. Tests were performed using a 0.05 significance level $(\alpha=5 \%)$. If the $\mathrm{p}$-value $\geq 0.05, \mathrm{H}_{\mathrm{o}}$ or $\mathrm{H}_{\mathrm{a}}$ rejected. If $\mathrm{p}$-value $\leq 0.05, \mathrm{H}_{\mathrm{o}}$ or $\mathrm{H}_{\mathrm{a}}$ accepted.

\section{F-Test}

F results of this calculation are compared with those obtained with use a level of risk or significant level of $5 \%$ or with degree freedom $=k(n-k-1)$ with the criteria as follows:

Ho rejected if Fstatistics $>$ Ftable \& Ho accepted if Fstatistics < Ftable.

\section{RESULT AND DISCUSSION}

\section{Descriptive Analysis}

Table 4.1. Descriptive Statistic

\begin{tabular}{cccccc}
\hline & $\mathrm{N}$ & Minimum & Maximum & Mean & $\begin{array}{c}\text { Std. } \\
\text { Deviation }\end{array}$ \\
\hline $\begin{array}{c}\text { Transparency } \\
(\mathrm{X} 1)\end{array}$ & 100 & 2.13 & 5.00 & 3.8663 & .7147 \\
$\begin{array}{c}\text { Accountability } \\
(\mathrm{X} 2)\end{array}$ & 100 & 2.50 & 5.00 & 3.9763 & .5668 \\
$\quad \begin{array}{l}\text { Service } \\
\text { Quality (X3) } \\
\text { Loyalty of } \\
\text { Zakat Payers } \\
\quad \text { (Y) }\end{array}$ & 100 & 2.50 & 5.00 & 4.0338 & .5386 \\
$\begin{array}{c}\text { Valid N } \\
\text { (listwise) }\end{array}$ & 100 & 2.50 & 5.00 & 3.9700 & .6463 \\
\hline
\end{tabular}


Table 4.1 shows the descriptive statistics owned by the zajat payers sampled in this research are 100 samples. From the total 100 samples used, it appears that the average loyalty of zakat payers amounted to 3.97 with a standard deviation of 0.6463 and a maximum value of 5 with a minimum value of 2.5. Transparency variable shows an average of 3.8663 with standard deviation of 0.7147 , maximum value of 5 and minimum value of 2.13 . Accountability variable shows an average of 3.9763 with standard deviation of 0.5668 , maximum value of 5 and minimum value of 2.5. Service quality variable shows an average of 4.0338 with standard deviation of 0.5386 , maximum value of 5 and minimum value of 2.5.

\section{Validity Test}

\begin{tabular}{ccccc}
\multicolumn{4}{c}{ Table 4.2. Validity Test Result of Transparency Variable $\left(\mathrm{X}_{1}\right)$} & \\
\hline \multirow{2}{*}{ Items } & $\begin{array}{c}\mathrm{r}_{\text {statistic }} \\
\text { (Pearson Correlation) }\end{array}$ & & $\mathrm{df}=(\mathrm{n}-2) ; \alpha=5 \%$ & Judgment \\
\hline 01 & 0.840 & $>$ & 0.374 & Valid \\
02 & 0.792 & $>$ & 0.374 & Valid \\
03 & 0.905 & $>$ & 0.374 & Valid \\
04 & 0.907 & $>$ & 0.374 & Valid \\
05 & 0.810 & $>$ & 0.374 & Valid \\
06 & 0.872 & $>$ & 0.374 & Valid \\
07 & 0.916 & $>$ & 0.374 & Valid \\
08 & 0.741 & $>$ & 0.374 & Valid \\
\hline
\end{tabular}

Based on above result in Table 4.2, it can be seen that $r_{\text {statistic }}$ values of transparency are greater than $r_{\text {table }}$ value. Hence, all items in questionnaire of transparency variable are valid, and all items can be used as instrument of data collection within research.

Table 4.3. Validity Test Result of Accountability Variable $\left(\mathrm{X}_{2}\right)$

\begin{tabular}{ccccc}
\hline Items & $\begin{array}{c}\mathrm{r}_{\text {statistic }} \\
\text { (Pearson Correlation) }\end{array}$ & & $\begin{array}{c}\mathrm{r}_{\text {table }} \\
\mathrm{df}=(\mathrm{n}-2) ; \alpha=5 \%\end{array}$ & Judgment \\
\hline 01 & 0.803 & $>$ & 0.374 & Valid \\
02 & 0.847 & $>$ & 0.374 & Valid \\
03 & 0.828 & $>$ & 0.374 & Valid \\
04 & 0.649 & $>$ & 0.374 & Valid \\
05 & 0.789 & $>$ & 0.374 & Valid \\
06 & 0.793 & $>$ & 0.374 & Valid \\
07 & 0.794 & $>$ & 0.374 & Valid \\
08 & 0.806 & $>$ & 0.374 & Valid \\
\hline
\end{tabular}

Data in Table 4.3 show that $r_{\text {statistic }}$ values of accountability are also greater than $r_{\text {table }}$ value. Thus, all items in questionnaire of accountability variable are valid and it can be used as instrument of data collection. 
Table 4.4. Validity Test of Service Quality Variable $\left(\mathrm{X}_{3}\right)$

\begin{tabular}{ccccc}
\hline Items & $\begin{array}{c}\mathrm{r}_{\text {statistic }} \\
\text { (Pearson Correlation) }\end{array}$ & & $\mathrm{df}=(\mathrm{n}-2) ; \alpha=5 \%$ & Judgment \\
\hline 01 & 0.887 & $>$ & 0.374 & Valid \\
02 & 0.807 & $>$ & 0.374 & Valid \\
03 & 0.628 & $>$ & 0.374 & Valid \\
04 & 0.766 & $>$ & 0.374 & Valid \\
05 & 0.858 & $>$ & 0.374 & Valid \\
06 & 0.854 & $>$ & 0.374 & Valid \\
07 & 0.775 & $>$ & 0.374 & Valid \\
08 & 0.642 & $>$ & 0.374 & Valid \\
\hline
\end{tabular}

Data in Table 4.4 also show that $r_{\text {statistic }}$ values of service quality are greater than $r_{\text {table }}$ value (0.374). Therefore, all items in questionnaire of service quality variable are valid and these items can be used as instrument of data collection.

Table 4.5. Validity Test Result of Loyalty of Zakat Payers Variable (Y)

\begin{tabular}{ccccc}
\hline Items & $\begin{array}{c}\mathrm{r}_{\text {statistic }} \\
\text { (Pearson Correlation) }\end{array}$ & & $\mathrm{df}=(\mathrm{n}-2) ; \alpha=5 \%$ & Judgment \\
\hline 01 & 0.909 & $>$ & 0.374 & Valid \\
02 & 0.807 & $>$ & 0.374 & Valid \\
03 & 0.894 & $>$ & 0.374 & Valid \\
04 & 0.773 & $>$ & 0.374 & Valid \\
05 & 0.873 & $>$ & 0.374 & Valid \\
06 & 0.826 & $>$ & 0.374 & Valid \\
07 & 0.894 & $>$ & 0.374 & Valid \\
08 & 0.759 & $>$ & 0.374 & Valid \\
\hline
\end{tabular}

Based on above data in Table 4.5, it can be seen that $r_{\text {statistic }}$ values of loyalty of zakat payers variable are greater than $r_{\text {table }}$ value. Therefore, all items in questionnaire of loyalty of zakat payers variable are valid, so these items can be used as instrument for data collection within researh.

\section{Reliability Test}

Table 4.6. Result Summary of Reliability Test

\begin{tabular}{lcccc}
\hline \multicolumn{1}{c}{ Variables } & $\begin{array}{c}\text { Reliability } \\
\text { Coefficient }\end{array}$ & & $\begin{array}{c}\text { Cut of } \\
\text { Value }\end{array}$ & Judgment \\
\hline Transparency $\left(\mathrm{X}_{1}\right)$ & 0.944 & $>$ & 0.60 & Reliable \\
Accountability $\left(\mathrm{X}_{2}\right)$ & 0.913 & $>$ & 0.60 & Reliable \\
Service quality $\left(\mathrm{X}_{3}\right)$ & 0.899 & $>$ & 0.60 & Reliable \\
Loyalty of zakat payers $(\mathrm{Y})$ & 0.922 & $>$ & 0.60 & Reliable \\
\hline
\end{tabular}


Refers to data in Table 4.6, it known that the reliability coefficient or $r_{\text {total }}$ values of transparency, accountability, service quality and loyalty of zakat payers variables are greater than the cut of value (0.60). Therefore, all items in questionnaire of transparency variable, accountability, service quality and loyalty of zakat payers variables within study are reliable so the questionnaire can be used as instrument for data collection within researh.

\section{Multicollinearity Test}

Table 4.11. Multicollinearity Test Result

\begin{tabular}{clcc}
\hline No & \multicolumn{1}{c}{ Variables } & VIF & Judgment \\
\hline 1 & Transparency $\left(\mathrm{X}_{1}\right)$ & 1.054 & No Multicollinearity \\
2 & Accountability $\left(\mathrm{X}_{2}\right)$ & 1.024 & No Multicollinearity \\
3 & Service quality $\left(\mathrm{X}_{3}\right)$ & 1.032 & No Multicollinearity \\
\hline
\end{tabular}

Based on data of multicollinearity test result in Table 4.11, it can be seen that Variance Inflation Factor (VIF) value of transparency $\left(\mathrm{X}_{1}\right)$ variable is 1.054 , VIF value of accountability $\left(\mathrm{X}_{2}\right)$ variable is 1.024 , and VIF value of service quality $\left(\mathrm{X}_{3}\right)$ variable of 1.032 each is less than 10. Therefore, it can be concluded that there is no multicollinearity in multiple regression analysis within study.

\section{Normality Test}

Table 4.12. Normality Test Result

\begin{tabular}{ccccc}
\hline Variable & $\begin{array}{c}\text { Value of } \\
\text { Kolmogorov } \\
\text { Smirnov }\end{array}$ & $\begin{array}{c}\text { Asymp. } \\
\text { Sig. }\end{array}$ & $\alpha$ & Judgment \\
\hline Standardized Residual & 0.638 & 0.811 & 0.05 & Normal \\
\hline
\end{tabular}

From data of normality test result in Table 4.12, it is obtained the value of asymptotic significant (asymp. sig.) of 0.811 is greater than value of $\alpha(0.05)$. Thus, research data of multiple regression analysis within study revealed a normal distribution.

\section{Heteroscedasticity Test}

Table 4.13. Heteroscedasticity Test Result

\begin{tabular}{cccc}
\hline No & $\begin{array}{c}\text { Independent } \\
\text { Variables }\end{array}$ & $\begin{array}{c}\text { Sig. } \\
\text { Value }\end{array}$ & Judgment \\
\hline 1 & Transparency $\left(\mathrm{X}_{1}\right)$ & 0.404 & No Heteroscedasticity \\
2 & Accountability $\left(\mathrm{X}_{2}\right)$ & 0.188 & No Heteroscedasticity \\
3 & Service quality $\left(\mathrm{X}_{3}\right)$ & 0.309 & No Heteroscedasticity \\
\hline
\end{tabular}

Data of heteroscedasticity test result in Table 4.13 show that the significant (sig.) value of transparency $\left(\mathrm{X}_{1}\right)$ variable is 0.404 , the significant value of accountability $\left(\mathrm{X}_{2}\right)$ variable of 0.188 , and the significant value of service quality $\left(\mathrm{X}_{3}\right)$ variable of 0.309 each is greater than 
$\alpha$ (0.05). Hence, it known that there is no heteroscedasticity in the model of multiple regression analysis within study.

Multiple Regression Analysis

Table 4.10. Summary of Multiple Regression Analysis Result

\begin{tabular}{cccccc}
\hline No. & Independent Variables & Coefficients & $\begin{array}{c}\mathrm{t}_{\text {statistic }} \\
\text { Value }\end{array}$ & & $\begin{array}{c}\mathrm{t}_{\text {table }} \\
\text { Value }\end{array}$ \\
\hline 1. & Transparency $\left(\mathrm{X}_{1}\right)$ & 0.481 & 6.604 & $>$ & 1.985 \\
$2 . \quad$ Accountability $\left(\mathrm{X}_{2}\right)$ & 0.337 & 4.698 & $>$ & 1.985 \\
$3 . \quad$ Service quality $\left(\mathrm{X}_{3}\right)$ & 0.265 & 3.677 & $>$ & 1.985 \\
\hline Constant Value of Regression $=0$ & & & & \\
Coefficient of Determination $=0.502$ \\
Value of $\mathrm{F}_{\text {statistic }}=34.294$
\end{tabular}

Regarding to the summary data of multiple regression analysis results in Table 4.10, then regression equation within thesis can be seen below:

$$
\mathrm{Y}=0+0.481 \mathrm{X} 1+0.337 \mathrm{X} 2+0.265 \mathrm{X} 3
$$

Following with the above statistics result about the equation of multiple regression analysis, so it can be given the several explanations below:

1. Constant value of multiple regression analysis in current thesis is 0 . This constant value shows that if transparency $\left(X_{1}\right)$, accountability $\left(X_{2}\right)$ and service quality $\left(X_{3}\right)$ variables are assumed have values of zero, so loyalty of zakat payers of zakat management organization in Purwokerto will be 0 .

2. Regression coefficient of transparency $\left(X_{1}\right)$ variable from multiple regression analysis in current thesis is 0.481 . The regression coefficient of $\mathrm{X}_{1}$ variable shows that transparency has a positive effect on loyalty of zakat payers, or it can be explained that if transparency increase, then it will be able to increase the loyalty of zakat payers of zakat management organization in Purwokerto of 0.481 .

3. Regression coefficient of accountability $\left(\mathrm{X}_{2}\right)$ variable from multiple regression analysis in current thesis is 0.337 . The regression coefficient of $\mathrm{X}_{2}$ variable shows that accountability has a positive effect on loyalty of zakat payers, or it can be explained that if accountability increase, then it will be able to increase the loyalty of zakat payers of zakat management organization in Purwokerto is 0.337 .

4. Regression coefficient of service quality $\left(\mathrm{X}_{3}\right)$ variable from multiple regression analysis in current thesis is 0.265 . The regression coefficient of $\mathrm{X}_{3}$ variable shows that service quality has a positive effect on loyalty of zakat payers, or it can be explained that if service quality increase, then it will be able to increase loyalty of zakat payers of zakat management organization in Purwokerto of 0.265. 


\section{F-Test}

To determine the Ftable value, this thesis uses the confidence level of 95 percent with the significant level $(\square)$ of 5 percent $(0.05)$; and degree of freedom $(\mathrm{df})=(\mathrm{k}-1)$ and $(\mathrm{n}-\mathrm{k})=(4-$ 1) and $(100-4)$. Thus it can be determined the Ftable value from the Table of F-Distribution in Appendix 11 is 2.68. Furthermore from the result summary of multiple regression analysis in Table 4.10, it can be seen that Fstatistic value within thesis of 34.294 is greater than Ftable value. Hence, it could be explained that transparency (X1), accountability (X2) and service quality (X3) variables have the significant simultaneously effect on loyalty of zakat payers (Y) of zakat management organization in Purwokerto, or it could be stated that the model of multiple regression analysis within thesis is fit with data of research (goodness of fit).

\section{R Square (Coefficiet Determination)}

Result summary of multiple regression analysis in Table 4.10 shows that adjusted $\mathrm{R}$ square value (coefficient of determination) within research is 0.502 . This determination coefficient shows that loyalty of zakat payers of zakat management organization in Purwokerto can be influenced by transparency (X1), accountability (X2) and service quality (X3) variables of 50.02 percent, while remaining of 49.98 percent can be explained by the other variables which are not examined in this thesis.

\section{T-Test}

To find out and testing the significance partially effect of transparency (X1), accountability (X2) as well as service quality (X3) variable on loyalty of zakat payers (Y), it used t-test from the output of multiple regression analysis. Following to the confidence level of 95 percent or $\alpha$ of 5 percent (0.05); and by using degree of freedom $(\mathrm{df})=(\mathrm{n}-\mathrm{k})=(100-$ 4) with two tailed of t-test $(\alpha=0.05)$; it is known the ttable value of \pm 1.985 (Table of $t$ Distribution in Appendix 12). Furthermore from result summary of multiple regression analysis in Table 4.14 above, it known that tstatistic value of transparency (X1) variable is 6.604 , tstatistic value of accountability (X2) variable within thesis is 4.698 , and tstatistic value of service quality (X3) variable of 3.677 .

\section{Hypothesis Testing}

\section{First of Research Hypothesis}

Based on t-test result of multiple regression analysis in Table 4.14 above, it can be seen that tstatistic value of transparency (X1) variable (6.604) is greater than value of table (1.985). Thus, Ho is rejected and Ha is accepted, so it known that transparency has positive and significant effect on loyalty of zakat payers of zakat management organization in Purwokerto. Thus, first hypothesis within thesis which states that transparency positively influence Loyalty of Zakat Payers is accepted.

\section{Second of Research Hypothesis}

Refers to the t-test result of multiple regression analysis, it has got the tstatistic value of accountability (X2) variable (4.698) is also greater than value of ttable (1.985). Thus, Ho is rejected and $\mathrm{Ha}$ is accepted, so it can be seen that accountability has a positive significantly 
effect on loyalty of zakat payers of zakat management organization in Purwokerto. Hence, second hypothesis of this thesis which states that accountability positively influence Loyalty of Zakat Payers is accepted.

\section{Third of Research Hypothesis}

T-test result of multiple regression analysis shows that tstatistic value of service quality (X3) variable (3.677) is also greater than value of ttable (1.985). Thus, Ho is rejected and Ha is accepted, so it can be seen that service quality has a positive and significant effect on loyalty of zakat payers of zakat management organization in Purwokerto. Therefore, third hypothesis which states that service quality positively influence Loyalty of Zakat Payers is accepted.

\section{DISCUSSION OF RESULT}

\section{The Effect of Transparency on Loyalty of Zakat Payers}

This research proves that transparency has a positive significantly effect on loyalty of zakat payers of zakat management organization in Purwokerto. This finding means that the better level of transparency is always followed by the higher level of zakat payers' loyalty of zakat management organization in Purwokerto. The results of this research support the theory Sharia Compliance, which one of sharia principle is transparency. Implementation sharia principle that is transparency in the zakat management financial report make it clear and in accordance with the existing reporting evidence, so the zakat payers can know clearly the management of zakat funds provided. The more transparent the management of zakat by zakat management organizations, zakat payers will be more confident and will tend to deliver zakat to zakat management organization.

\section{The Effect of Accountability on Loyalty of Zakat Payers}

Current study found that accountability has a positive significantly effect on loyalty of zakat payers of zakat management organization in Purwokerto. This result means that the better level of accountability is always followed by the higher level of zakat payers' loyalty of zakat management organization in Purwokerto. The results of this research support the theory Sharia Compliance, which one of sharia principle is accountability. Implementation sharia principle that is accountability in the zakat management organization increase trust of muzakki because zakat payers can know clearly the responsibility of zakat management organization of zakat funds provided. The more accountable the management of zakat by zakat management organizations, zakat payers will be more confident and will tend to deliver zakat to zakat management organization.

\section{The Effect of Service Quality on Loyalty of Zakat Payers}

Result of current study proves that service quality has a positive significantly effect on loyalty of zakat payers of zakat management organization in Purwokerto. This causal relationship means that the better level of service quality is always followed by the higher level of zakat payers' loyalty of zakat management organization in Purwokerto. The results of this research support the theory Consumer Trust, which one of good service quality is one of 
indicator to increase consumer trust. Implementation of good service quality in the zakat management organization increase trust of muzakki because zakat payers will be more confident by the zakat management organization has taken the most appropriate steps, which will benefit and help zakat payers in achieving the goal. The more accountable the management of zakat by zakat management organizations, zakat payers will be more confident and will tend to deliver zakat to zakat management organization. The better the quality of service in the organization of zakat management, the higher the trust of muzakki that will affect the muzakki loyalty that will be higher to pay zakat on the zakat management organization.

\section{CONCLUSION}

Based on the results of research about the effect of transparency, accountability, and service quality toward loyalty of zakat payers can be summarized as follows:

1. Based on the result of multiple regression analysis, tstatistic value of transparency is greater than value of ttable. Thus, Ho is rejected and Ha is accepted, so it is revealed that transparency has a positive and significant effect toward loyalty of zakat payers. Finding of this research supports the result of previous study was conducted by Septiarini (2011) and Nunung Nur Hayati (2014).

2. Refers to the result of multiple regression analysis, it has got tstatistic value greater than value of ttable. Thus, Ho is rejected and $\mathrm{Ha}$ is accepted, so it known that accountability has a positive and significant effect toward loyalty of zakat payers. This study result is in line with finding of previous study by Assaggaf (2016) and Lusi (2017).

3. Following the result of multiple regression analysis above, it known that tstatistic value greater than value of ttable. Thus, Ho is rejected and Ha is accepted, so it can be seen that service quality has a positive and significant effect toward loyalty of zakat payers. Result within study is consistent with the previous study by Hanifah (2015) and Bahaudin (2018).

\section{IMPLICATION}

In order to increase the loyalty of zakat payers, zakat management organization in Purwokerto need to pay attention on transparency, accountability and service quality. The ways can be done by always provide an adequate information about time of zakat payment and calculation method, provide the regular and up to date reports related to the amount of zakat that has been entered and the amount of zakat that has been issued to financing the mass. In addition, zakat management organization in Purwokerto must be able to become as a trustworthy organization of zakat management, provide the excellent services to all zakat payers according to the Islamic principles, and continues to innovate through the development of zakat services which is supported by highly capable human resources and integrated technology. 
Following to the above various limitations within study, the next researchers should conduct the study about antecedents of zakat payers' loyalty with the wider range of research object, and it is necessary to develop this research model by entering or adding the other various independent variables (for example: religious commitment and image of zakat management organization), add the moderator variable (for example: trust and innovative service), and examine the role of zakat payers' satisfaction as mediator variable. The next researchers are also needs to select or examine another research subjects more broadly, for example zakat payers of zakat management organization in Banyumas Regency or the other regions, such as Purbalingga, Banjarnegara and Cilacap in order to obtain the better result of study, the objective study result and the result of study that can be more generalized.

\section{REFERENCES}

Abu-Tapanjeh, A.M. 2009. Corporate Governance From The Islamic Perspective: A Comparative Analysis with OECD Principles. Critical Perspectives On Accounting 20:556-567.

Ar Rahman, M.A.M. 2003. Pustaka Cerdas Zakat: 1001 Masalah Zakat dan Solusinya. Cet I: Lintas Pustaka Jakarta.

Assaggaf, M.A. 2016. Pengaruh Akuntabilitas dan Transparansi Pengelolaan Zakat Terhadap Minat Muzakki Membayar Zakat. Skripsi. Fakultas Ekonomi dan Bisnis Islam Universitas Alauddin Makassar.

Aziz, M. 2017. Strategi Pengelolaan Zakat Secara Produktif pada Lembaga Amil Zakat dalam Tinjauan UU RI Nomor 23 Tahun 2011 tentang Pengelolaan Zakat (Studi Kasus di Nurul Hayat kantor cabang Tuban periode 2015-2016). Al Hikmah: Jurnal Studi Keislaman, Volume 7, Nomor 1, Februari 2017.

Budiman, A.A. 2010. Membangun Akuntabilitas Lembaga Pengelola Wakaf. IAIN Walisongo Semarang.

Fadilah S., et al. 2012. Membangun Kepercayaan Kosumen: Faktor Penting Pada Lembaga Amil Zakat Seluruh Indonesia. Jurnal. (ISSN 2089-3590, Vol 3, No.1, Th, 2012).

Fadilah, S. et al. 2017. Organisasi Pengelola Zakat (OPZ):Deskripsi Pengelolaan Zakat Dari Aspek Lembaga Zakat. Kajian Akuntansi PP:60-74 Vol 18 No.1 September 2017.

Faisal, Q. 2011. Sejarah Pengelolaan Zakat di Dunia Muslim dan Indonesia. Jurnal Analisis, Volume XI NO. 2: 241-272, 2011.

Fatmawati, L. 2017. Pengaruh Sharia Compliance, Transparansi, Akuntabilitas,dan Kompetensi Sumber Daya Manusia (SDM) Terhadap Pengelolaan Dana Zakat. Skripsi. Fakultas Ekonomi Universitas Negeri Padang.

Ghozali, I. 2012. Aplikasi Analisis Multivariate dengan Program IBM SPSS 20. Semarang: Badan Penerbit - Universitas Diponegoro. 
Ghozali, I. 2016. Aplikasi Analisis Multivariate Dengan Program IBM SPSS 23. Badan Penerbit Universitas Diponegoro Semarang.

Hakim, M.M. 2014. Pengaruh Transparani dan Akuntabilitas Pengelolaan Zakat Terhadap Minat Muzakki di Rumah Zakat Semarang. Skripsi. Fakultas Ekonomi dan Bisnis Islam IAIN Walisongo Semarang.

Hamidi, N. 2013. Analisis Akuntabilitas Publik Organisasi Pengelola Zakat Berdasarkan Aspek Pengendalian Intern dan Budaya Organisasi. Jurnal Ekonomi dan Bisnis Islam, Universitas Sebelas Maret. Volume VIII, No. 1, Desember 2013.

Hamidiyah, E. 2016. Ramadhan Momentum Menata Kembali Perekonomian Umat. 20 September 2018. www.pusat.baznas.go.id.

Hanafiah, R. R. 2016. Pengaruh akuntabilitas, transparansi, kapasitas sumber daya manusia, dan pengawasan intern terhadap pengelolaan keuangan daerah. Jurnal Akuntasi Pascasarjana Universitas Syiah Kuala. Volume 5, No. 4, November 2016.

Hanifa, A. 2015. The Sharia-compliance of Financial Reporting Practices: A Case Study on Waqf. Journal of Islamic Accounting and Business Research, Vol. 6 ISS 1 pp.

Hansen, M. H., Morrow, J. L., \& Batista, J. C. 2002. The Impact of Trust on Cooperative Membership Retention, Performance, and Satisfaction: An Exploratory Study. International Food and Agribusiness Management Review, 5(1), 41-59. https://doi.org/10.1016/S1096-7508(02)00069-1.

Hasan, Muhammad. 2011. Manajemen Zakat. Cet I: Idea Press Yogyakarta.

Indonesia Zakat and Development Report (IZDR). 2008. Zakat Outlook 2009: Mampukah Zakat Berperan Serta Membangun Bangsa. Seminar Zakat Outlook 2009 di Graha Niaga Jakarta 2008.

Johnson, D., \& Grayson, K. 2005. Cognitive and Affective Trust in Service Relationships. Journal of Business Research, 58(4), 500-507. https://doi.org/10.1016/S01482963(03)00140-1.

Khaerani, R. 2013. Akuntabilitas dan Transparansi Lembaga Pengelola Zakat Terhadap Kualitas Lembaga Amil Zakat (Pandangan Muzakki dan Amil Zakat pada Dompet Dhuafa SulSel). Skripsi. Universitas Hasanuddin Makassar.

Kholmi, M. 2012. Akuntabilitas dan Pembentukan Perilaku Amanah dalam Masyarakat Islam. Jurnal Studi Masyarakat Islam, 15, 63-72.

KNKG. 2006. Indonesia's Code of Good Corporate Governance.

Muhammad. 2016. Potensi Zakat Nasional Mencapai Rp. 217 triliun. 20 September 2018. www.pusat.baznas.go.id.

Nugraha, S. 2013. Pengaruh Persepsi Akuntabilitas dan Transparansi Keuangan Terhadap Minat Muzakki Membayar Zakat Pada Lembaga Amil Zakat (Studi Kasus BMH dan LMH Bondowoso). Skripsi. Fakultas Ekonomi Universitas Jember. 
Nur'aini, H. 2015. Pengaruh Kualitas Pelayanan, Citra Lembaga, dan Religiusitas Terhadap Minat Muzakki Menyalurkan Zakat Profesi PKPU Cabang Yogyakarta. UIN Sunan Kalijaga.

Nurhayati, N. et al. 2014. Pengaruh Kualitas Informasi Akuntansi, Akuntabilitas dan Transparansi Pelaporan Keuangan Terhadap Tingkat Penerimaan Dana Zakat Pada Badan Amil Zakat (BAZ) di Jawa Barat. Prosiding SNAPP 2014 Sosial, Ekonomi, Dan Humaniora. ISSN 2089-3590 EISSN 2303-2472.

Nurhayati, S., \& Wasilah. 2012. Akuntansi Syariah di Indonesia. Jakarta: Salemba Empat.

Nurrizkiana, B., Handayani, L., \& Widiastuty, E. 2017. Determinan Transparansi dan Akuntabilitas Pengelolaan Keuangan Daerah dan Implikasinya Terhadap Kepercayaan Public-Stakeholders. Jurnal Akuntansi Dan Investasi, 18(1), 28-47. https://doi.org/10.18196/jai.18159.

PID BAZNAS. 2017. Peraturan Pemerintah Republik Indonesia (PP) Nomor 14 Tahun 2014 Tentang Pelaksanaan Undang-Undang (UU) Nomor 23 Tahun 2011 Tentang Pengelolaan Zakat.

Rahma, N.H.S. 2011. Pengaruh Akuntabilitas dan Transparansi Terhadap Loyalitas Berzakat pada Lembaga Pengelola Zakat di Kota Surabaya. Skripsi. Fakultas Ekonomi dan Bisnis Universitas Airlangga Surabaya.

Rahmadita. 2012. Optimalisasi peran lembaga amil zakat dalam kehidupan sosial. Jurisdictie, Jurnal Hukum dan Syariah, Volume 3 Nomor 1: 24-34.

Rahmananursajid, A. 2008. Akuntabilitas dan Transparansi dalam Pertanggungjawaban Pemerintah Daerah untuk Mewujudkan Pemerintahan Yang Baik di Daerah (Studi di Kab. Kebumen). Tesis. Universitas Diponegoro Semarang.

Septiarini, F. D. 2011. Pengaruh Transparansi dan Akuntabilitas Terhadap Pengumpulan Dana Zakat, Infaq dan Shodaqoh pada LAZ di Surabaya. Jurnal Akuntansi. Akrual 2 (2) (2011): 172-199 e-ISSN: 2502-6380.

Zeithaml, V.A., Parasuraman, A. and Berry, L.L. 1990 Delivering Quality Service, The Free Press, New York, N.Y. 